\title{
Feminist Approaches to Educational Leadership in Disadvantaged Rural Communities
}

\author{
Graeme Edwards \\ University of Johannesburg, Johannesburg, South Africa
}

Copyright $(2018$ by authors, all rights reserved. Authors agree that this article remains permanently open access under the terms of the Creative Commons Attribution License 4.0 International License

\begin{abstract}
Playing host to many leaders of South Africa's transition to democracy, the historic schools continue to contribute to the education of learners in disadvantaged rural communities. Within the leadership narratives of these schools are the lived daily experiences of female educational leaders whose voice has been largely absent from main stream leadership discourse. Problematizing this silence, this paper draws on critical feminist leadership theory to explore social justice interpretations of female leaders in South Africa's historic schools. Data were collected through a qualitative research paradigm and from a critical feminist perspective. The aim of the study was to analyse and conceptualise educational leadership in relation to power and social justice in the post-Apartheid era. Contained within the findings are multiple narrations of leadership for social justice and an alternative interpretation to feminist servant leadership. In addition, the findings unlocked insights into the relationship between curriculum management, instructional leadership and critical pedagogy.
\end{abstract}

Keywords Feminist Research Methodologies, Social Justice, Critical Pedagogy, Servant Leadership

\section{Introduction}

Perumal [1] observes that the role of educational leaders "has changed considerably over the past several decades from manager, to street-level bureaucrat, change agent, instructional leader, educational leader, and more recently to transformational leaders". Within the ever evolving functions of educational leadership, main steam instructional leadership primarily focuses on shaping the "conditions in the school that directly impact learning outcomes for students" [2]. Within the context of disadvantaged rural communities, this paper explores perspectives of curriculum management and instructional leadership by female educational leaders. In addition, the relationship between instructional leadership, social justice and critical pedagogy are dissected and analyzed through a critical feminist lens. While the interpretation of instructional leadership by female educational leaders in disadvantaged rural communities does not necessarily conflict with the mainstream discourse, the findings presented in this paper do, however, offer alternative interpretations of instructional leadership. Blackmore [3] agitates for a reconstructed view of leadership, and argues in favor of feminist leadership that "counters the emphasis on individualism, hierarchical relationships, bureaucratic rationality and abstract moral principles". Responding to their specific socio-economic contexts, the participants demonstrated an interpretation of instructional leadership characterized by a reduction in power hierarchies and a rejection of individualism in leadership relationships. Moreover, in this interpretation, instructional leadership is manifested through practices which seek to decolonize education, address issues of social justice, advance transformative leadership practices, and which privilege collaborative and reciprocal curriculum engagements. These findings unlock the silent voices of rural educational leaders and respond to the paucity of critical work on the lived experiences of female educational leaders in disadvantaged rural communities.

\section{Theoretical Underpinnings}

Although the participants did not proclaim themselves as feminists, this study drew on critical feminist theory to explore the lived educational leadership experiences of females in disadvantaged rural communities. Critical theory, the foundation stone for critical feminist theory, was the conceptual frame for this paper. Summer [4] observes that critical theory "frames the way we look at the world which involves the cultivation of a critical attitude on all levels". Critical feminist, bell hooks [5], observes that feminists oppose all forms of oppression of women caused largely by living in predominantly patriarchal societies. For the purposes of this paper key tenets of critical feminist theory were selected and grouped into three broad themes. In this 
section each will be identified, explored and contextualised in relation to instructional leadership.

\subsection{Critical Feminist Theory, Gender, Patriarchy and Social Justice}

The conceptualisation of gender is an important consideration in critical feminist theory. Cudd and Andreasen [6] record that "since the beginning of the second wave, 'gender' has been one of the most central concepts of feminism". They explain that the terms "sex" and "gender" were introduced into the feminist discourse in "order to distinguish between the biological and social aspects of sexual difference" [6]. In this distinction, "sex refers to biological differences between males and females", while "gender refers to socially caused differences" [6]. Critical feminists contend that social injustices are often associated with the oppressive forces of patriarchy and gender discrimination. Gender stereotypes are formulated in patriarchal societies by assigning traditional roles to men and women. The "construction" of gender with its associated traditional practices and cultural expectations are closely aligned to patriarchal practices in society. Critical feminists argue that these structures, which privilege male dominance and result in the subordination and oppression of women, are determined by gender and are therefore central to the critical feminist perspective.

Critical feminists challenge issues of social justice not only to raise awareness, but also to being about societal change. Lyman, Strachan and Lazaridou [7] contend that speaking out against social injustice is achieved by "being able to discuss a problem when viewpoints differ, being political through advocacy, and lobbying". In as much as critical feminists seek to advocate for social justice and bring about change, their vision is also emancipatory in that "it imagines something better for human beings" [4]. Addressing issues of social justice therefore requires a critical perspective, one that interrogates oppressive patriarchal structures.

Edwards [8] points out that "mainstream educational leadership theories are dominated by male writers, presenting a largely male perspective, and therefore tend to mostly ignore feminist interpretations of educational leadership". Drawing on Lumby and Coleman, Bush [9] corroborates this assertion and describes this scenario as the "white, male, middle class norm". Furthermore, describing gender related challenges experienced by female educational leaders in Zimbabwean schools in disadvantaged communities, Zikhali [10] found that "gender-related challenges manifest in negative attitudes, labelling, stigmatisation, resentment and rejection as leaders from both society and colleagues". Issues of gender and patriarchy therefore hold significance for a female interpretation of instructional leadership in rural disadvantaged communities.

\subsection{Critical Feminist Theory and Power}

Conceptualising power is central to feminist theory [11,12]. In critiquing power from a critical feminist perspective, however, Allen [13] contends that power is understood "not as a resource or critical social good, but instead as a relation of domination". From a feminist perspective, however, power as domination may also be interpreted as power in the form of oppression, patriarchy and subjection. Whilst the traditional Marxist perspective of power and domination is understood on the basis of class exploitation [13], critical feminist Hartsock [11] offers a different vision of power and materialism. She argues that "power and domination have consistently been associated with masculinity". For feminists, therefore, an understanding of power is conceived within patriarchy, gender inequality, the oppression of women by men and the dominant ruling culture [11].

Defying the patriarchal assumption that power is defined by the notion of "power over", [11] offers an alternative interpretation of power. This perspective replaces power dominion over others in competitive situations with power "through action in connection with others with whom one shares a common life and common concerns". Conceptualising power in this way offers a view of "power through" as opposed to "power over". In another perception, Gore [14] examines the "conception of power as property". In this interpretation, Gore refers to a "particular relationship between the agents of empowerment and those who are empowered" [14]. Furthermore, Gore [14] contends that the power relationship must be initiated and exercised in order that "even these liberatory discourses can function as regimes of truth".

Issues of power in the educational leader-follower relationship hold significance for the interpretation of instructional leadership by female leaders in disadvantaged rural school communities. It is at this juncture that we draw attention to critical pedagogy as a central concept in the feminist educational leadership discourse. Aliakbari and Faraji [15] note that critical pedagogy is "concerned with transforming relations of power which are oppressive and which lead to the oppression of people". In addition, McLaren [16] describes critical pedagogy as "fundamentally concerned with the centrality of politics and power in our understanding of how things work". Centralising a political perspective, and drawing on Freire [17] and Giroux [18]; Aliakbari and Faraji [15] posit that the "most important theme in critical pedagogy is the belief that education systems are political". Schools are therefore regarded as a microcosm of broader society, thus implying that societal issues of power and inequality are reflected in schools.

Darder, Mayo and Paraskeva [19] observe that the power relationships in many societies are immutable remnants of their colonial history. These remnants are the "sites of struggle" and are most relevant to critical pedagogy. In South Africa, the metaphorical hangover of colonialization and Apartheid produced numerous "struggle sites". Schools 
in rural communities are particularly vulnerable to the resultant inequalities of oppressive political regimes. Balfour [20] draws attention to the poor state of South Africa's rural schools, noting poor curriculum delivery and a lack of teaching resources. In addition, Lather [21] contends that "relations of dominance" are perpetuated in post-colonial contexts and cautions that "even emancipatory education is a site of struggle and contestation, wherein relations of dominance re-emerge".

The practical application of critical pedagogy ultimately rests with the teacher. Giroux [18] defines the teacher as a "transformative intellectual", "one who exercises forms of intellectual and pedagogic practice that attempt to insert teaching and learning directly into the political sphere by arguing that schooling represents both a struggle for meaning and a struggle over power relations". In the context of critical pedagogy, and explaining Giroux's reference to teachers as "transformative intellectuals", Yoon [22] points out that the "transformative intellectual 'questions' the way knowledge is made and shared". Furthermore, critical feminist pedagogues connect the concept of the teacher as a transformative intellectual to their particular environment and physical location [23]. In this analysis Perumal argues for the "importance of recognizing the contexts in which teachers ply their trade and the positive or negative experiences that they undergo by virtue of being located in particular environments" [23]. This assertion creates the necessary "struggle sites" for differing manifestations of power and knowledge.

\subsection{Critical Feminist Theory and Instructional Leadership}

Glatthorn [24] contends that "one of the central functions of educational leadership is to provide instructional leadership". Moreover, he suggests that these "functions" include development of the assessment agenda, correlation of the curricula and an analysis of resources required to implement and develop the curriculum [24]. Thacker, Bell and Schargel [25] corroborate this view and explain that "the principal must provide the leadership essential for student learning". Instructional leadership is therefore a complex collection of curriculum knowledge, leadership skills, judgements and pedagogy. As a research area, however, female instructional leadership in South African disadvantaged communities has received little interest (Bush, Joubert, Kiggundu and van Rooyen, 2010: 164).

It has been established that issues of power are central to critical feminist theory and, by implication, that critical pedagogy is central to the discourse on critical feminist educational leadership. Enacting instructional leadership from a critical pedagogic perspective calls for engagement through a dialogical approach. Explaining the dialogical approach with the Roma marginalised community, Flecha and Soler (2016: 282) report on how the school transformed its approach by involving families. They note that this was a "key to helping them develop a sense of belonging to the school and a belief in possibility, not only on an individual, but also on a collective basis". The practical instructional leadership practices involved community participation in decision making as well as family and community involvement in children's learning. The impact of this approach resulted in both an improvement in standardised test scores and a significate reduction in absenteeism. Instead of perpetuating practices that promote segregation, dialogical approaches rather engage learners, families and the community. This strategy personifies the actions of a critical pedagogue, one seeking transformation and equity for a marginalised community.

The transformational instructional leadership of a dialogical approach exemplifies Freire's (1970) reference to "untested feasibility". In this instance, "untested" does not imply "unfeasible", but rather that which can potentially transform the existing reality. Flecha and Soler (2016: 288) argue that "when educational actions are shaped and implemented in dialogue with the community, this 'untested' reality is imagined as possible and becomes a reality that can be created by transforming the existing reality". Critical pedagogy requires instructional leaders to address issues of inequality and oppression, particularly as they relate to marginalised communities or minority groups. Instructional leadership that implements dialogic learning with community members works towards transforming education so that the world of minority and marginalised groups "no longer need to be separate and incompatible realities" (Flecha and Soler, 2016: 288).

The critical feminist perspective privileges pedagogic enterprise as a significant component of educational leadership. Perumal [1] notes that "even as women move into educational leadership roles, several studies report that women educational leaders continue to ensure that teaching and learning remain the central focus of the rhythms of the educational enterprise". In this way, female educational leaders assume leaderful practices and ensure that "instructional leadership remains central to the enterprise of education" [1]. Corroborating Perumal's assertion, Irwin [26] explains that the emphasis of instructional leadership is "learner process rather than product, and dialogue among participants" through which "cooperative learning becomes the key to empowerment and liberation". In practice, however, critical feminist pedagogy is characterised by the creation of knowledge in a collaborative learning environment, where participant ideas count and where participants take responsibility for their own learning.

\section{Research Methodology}

As this was an exploratory study about the experiences of female educational leadership, a qualitative approach with case study research design was most suitable. Yin [27] contends that case study methods are used to "understand 
real life phenomena in depth" and that such understanding is encompassed with "contextual conditions". Furthermore, this study adopted critical feminist research methodologies. These methodologies privilege women's voices and critique gendered relations of power from the perspective of the lived experiences of women. Moreover, critical feminist research methodologies critique hierarchies, power imbalances and androcentric bias through a reflexive lens.

The schools in this study are located in disadvantaged rural contexts in South Africa. Here disadvantaged is defined as, "something which causes one to be in an unfavourable position", and, "underprivileged socially" [13]. "Disadvantage" in the context of these school communities refers to deprivation of some basic necessities including, adequate housing and sanitation, access to adequate infrastructure, medical facilities and education [28]. Five schools were selected for this study of which three are located in the Eastern Cape Province, and two in Kwa-Zulu Natal.

The schools in this study are known as 'historic schools' and were all founded by missionary organisations, including the American Board of Missionaries and missionary organizations of the Methodist, Anglican and Catholic Churches. The oldest of the schools was founded in 1846, and the youngest in 1923. However, the system of Bantu Education (Act No. 47 of 1953) institutionalized racism in the South African school system by willfully providing grossly inferior education for black children. Bantu education thus resulted in the historic schools losing their independence and being taken over by the Education Department of the Apartheid Government. The governance and the funding of the schools were reassessed in 1994, when the first democratic elections took place in South Africa [29]. Of the five schools in the study, one is governed as an Independent School, receiving a partial financial state subsidy, while the other four fall under the respective national and provincial education authorities.

Contrasting the tragedy of Bantu education, the post-Apartheid era heralded "hope for education in South Africa" [29]. This "hope" is manifested through the Historic Schools Restoration Project (HSRP). Focusing on the physical, educational and cultural renewal of the historic schools, the mission of the HSRP is:

To revitalise the rich heritage of the historical schools and transform them into sustainable and aspirational African institutions of educational and cultural excellence [29].

Archbishop Ndungane, the Director of the HSRP, argues that the "hope for education in South Africa" is found in the "educational renewal projects" [29]. The manifestation of this 'hope' is realised by the contribution of the HSRP to the secondary schools identified for renewal.

Table 1 provides a summary of the biographical details of the schools in this study. The names of the schools are represented as pseudonyms.
Table 1. Biographical details of the schools in the study

\begin{tabular}{|c|c|c|}
\hline School & Year founded & Geographical context \\
\hline Amanzi College & 1846 & $\begin{array}{c}\text { Amanzimtoti } \\
\text { Kwa-Zulu Natal }\end{array}$ \\
\hline Spring Valley College & 1869 & $\begin{array}{c}\text { Inanda } \\
\text { Kwa-Zulu Natal }\end{array}$ \\
\hline Hope Town School & 1855 & $\begin{array}{c}\text { Fort Beauford } \\
\text { Eastern Cape }\end{array}$ \\
\hline Rolling Hills College & 1856 & $\begin{array}{c}\text { Kieskammashoek } \\
\text { Eastern Cape }\end{array}$ \\
\hline Ubuntu College & 1923 & $\begin{array}{c}\text { Vryheid } \\
\text { Kwa-Zulu Natal }\end{array}$ \\
\hline
\end{tabular}

Through purposive sampling thirteen female participants in disadvantaged, rural school communities were included in this study. Although the participants were all women, diversity was achieved insofar as age, race and length of experience in school leadership positions. Of the participants, two were school principals and eleven held other positions of educational leadership. In-depth interviews, walking interviews, focus groups, dyads, observations and archival document analysis were used as the main instruments for data collection. The narratives in this paper, however, are drawn from five in-depth interviews, each approximately forty minutes in duration. The aim of the interviews was to explore the leadership experiences of female educational leaders in disadvantaged rural communities. Each interview commenced with a brief introduction and overview of the aims of the study. In addition, every participant signed the letter of consent as required by the University of Johannesburg prior to the commencement of the interview. Furthermore, ethical clearance was obtained from the Ethics Committee of the University of Johannesburg.

Table 2 represents selected autobiographical information and a professional profile of the participants whose narratives are used in this paper.

Table 2. Autobiographical information and professional profile of participants

\begin{tabular}{|c|c|c|c|}
\hline Name & School & Position held & $\begin{array}{c}\text { Age } \\
\text { Race }\end{array}$ \\
\hline Jane & Spring Valley College & Principal & $\begin{array}{c}55-60 \\
\text { white }\end{array}$ \\
\hline Mildred & Spring Valley College & Deputy Principal & $\begin{array}{c}40-45 \\
\text { Coloured }\end{array}$ \\
\hline Alison & Ubuntu College & Principal & $\begin{array}{c}55-60 \\
\text { White }\end{array}$ \\
\hline Mary & Rolling Hills College & Deputy Principal & $\begin{array}{c}40-45 \\
\text { black }\end{array}$ \\
\hline Grace & Rolling Hills College & Head of Department & $\begin{array}{c}35-40 \\
\text { black }\end{array}$ \\
\hline
\end{tabular}

Data were transcribed verbatim from voice recordings and analysed thematically through qualitative data analysis, critical discourse analysis (CDA), and feminist critical discourse analysis (FCDA). Reflexivity and critical reflection are positioned as defining features of critical feminist researchers. Hesse-Biber [30] contends that a "critical feminist approach positions the research process in in time, place, culture and situation, and promotes the use of 
researchers' reflexivity and critical reflection". FCDA extends the function of CDA and views the use of language through a feminist lens. Lazar [31] explains that FCDA brings together CDA and feminist thought with the specific aim of advancing the "rich and nuanced understanding of the complex workings of power and ideology". Moreover, FCDA is centred on how "gender ideology and gendered relations of power are (re)produced, negotiated and contested in representations of social practices, in social relationships between people, and in people's social and personal identities in text and talk" [31]. FCDA is therefore concerned with issues of societal patriarchy, power and dominance.

\section{Findings and Discussion}

Techniques of qualitative data analysis and FCDA produced three themes which pertain to the aims of this paper. In this section I present and analyse interpretations of instructional leadership by female educational leaders in disadvantaged rural communities.

\subsection{Curriculum Management and Instructional Leadership}

In this section, I present the findings of three participants' response to questions pertaining to curriculum delivery and academic matters.

Mildred stated:

I am responsible for all the academic matters in this school. I plan the time table, assessment programmes and report schedules. I also meet with the subject Heads of Department and help them to plan their meetings and curriculum. A very big part of my job is completing all the paper work for the education department, you know, for the matric exam.

In this excerpt, Mildred explains her role as the Head of Academics. She makes particular reference to planning and administrative tasks. Mildred stated that "A very big part of my job is completing all the paper work for the education department."

Extending this theme, Grace commented:

It is important that I get all the paper work right. This means that forms are completed and submitted to the department. It is an important part of the academic programme. I am quite good at this!

Grace's response highlights the time and attention given to administrative processes. She stressed the importance of correct submissions, noting "It is important that I get all the paper work right" and "It is an important part of the academic programme."

In the analysis of Mildred's and Grace's responses I draw a distinction between curriculum and instruction. Parkay,
Anctil \& Hass [32] point out that "curriculum and instruction are interdependent", but differentiate between the two noting that the "what, is the curriculum" and the, "how, is instruction" (Parkay, Anctil \& Hass [32]. Whist the administrative processes to which Mildred and Grace refer support teaching and learning, we contend that they are more closely associated with curriculum management than instructional leadership. As neither Mildred nor Grace is principals, it is presumed that the curriculum management/administrative functions have been delegated to them. Whilst Hallinger and Wen-Chung [2] concede that certain day-to-day tasks may be delegated to others, they insist the key instructional leadership responsibility is that of the principal. In light of Hallinger and Wen-Chung's assertion, it is argued therefore that administrative tasks do not constitute instructional leadership.

It has been established that as the Head of Academics at Spring Valley College, Mildred's primary function was one of curriculum management. Jane, the principal of Spring Valley College, added:

I have never run a school without curriculum change. The education department has been making curriculum changes since the 1980s. I have spent much more time engaging in managing curriculum change than any type of curriculum leadership or innovation, actually, the curriculum is prescriptive and leaves no room for excitement and innovation.

The other thing is the subsidy. Because of this we have to comply with the department. This limits our curriculum leadership and my freedom to lead my staff in their teaching. We have to submit how many tests we do, what they are about, our work schedules. It is all pre-determined. If we don't comply our survival is threatened. I have a sort of bubbling resentment against them the whole 'flipping' time. But at the same time our subsidy last year was over two million rand!

In essence, I say to my staff; if these is a space for innovation and freedom, take it! To be honest, I am too busy dealing with survival and change stuff to be involved in innovative curriculum leadership. But let me say, I chose people I can trust to lead the curriculum, so in a way it is distributed. I have to admit that I do not lead the curriculum directly. There is creativity and innovation, but it does not come from me!

In this excerpt, Jane expresses her frustration relating to the Education Department's external control of curriculum and the frequent changes imposed. Jane's reference to "curriculum leadership" is considered synonymous with instructional leadership. Offering two reasons, Jane claims that the external curriculum controls hinder her ability as an instructional leader. Firstly, adhering to departmental regulations stifles creativity and innovation. Jane stated that "I have spent much more time engaging in managing 
curriculum change than any type of curriculum leadership or innovation." Jane's reference to "managing curriculum change" suggests that her time is devoted to curriculum management as opposed to curriculum or instructional leadership. Secondly, Jane suggests that the school's dependence on the subsidy further hinders her ability to exercise instructional leadership. She stated that "Because of this we have to comply with the department. This limits our curriculum innovation and my freedom to lead my staff in their teaching practice." This finding suggests that the financial subsidy could be considered as a vehicle to enforce curriculum compliance.

The frustrations emerging from external curriculum control and limited freedom for curriculum innovation suggest a disconnection between the curriculum authors and the needs of schools in rural, disadvantaged communities. Cornbleth [33] refers to this phenomenon as a "conceptual separation", where the "prevailing technocratic conception views curriculum as a tangible product, usually a document or plan for instruction in a particular subject". Instead, Cornbleth [33] argues for "conceptual integration", where curriculum is conceived as a "contextualised social process [that] encompasses both subject matter and social organizations, and their interactions". Moreover, unlike technocratic models, which are analytic, contextualised social processes are a "dynamic interaction among policy, planning, enactment, and their structural and socio-structural contexts" [33]. Cornbleth privileges the notion of conceptual integration which leads to a curriculum in context. The findings in this study suggest that there is a conceptual misalignment in the design of the curriculum in relation to the socio-cultural context in disadvantaged, rural school communities.

Tensions arising from external curriculum administrative demands reduce the principals' ability to provide instructional leadership. Hallinger and Wen-Chung [2] posit that a "core feature of instructional leadership has been its emphasis on the principal's direct engagement with the teaching and learning process". Drawing on Hallinger and Wen-Chung's assertion, the observations of the previous section highlight two issues. Firstly, academic administrative procedures, although important to the academic programme, do not constitute instructional leadership. Secondly, administrative procedures are limiting agents of instructional leadership. Jane endorses the latter assertion by stating "I have to admit that I do not lead the curriculum directly. There is creativity and innovation, but it does not come from me!"

The positioning of power is an important consideration for female interpretations of instructional leadership. The study found that despite the policy changes introduced in the post-Apartheid era, South African educational leaders still experience the hierarchical and bureaucratic power structures of the past. Curriculum compliance through reporting structures and funding models result in educational leaders being better described as curriculum managers than instructional leaders. Furthermore, the findings reinforce the difference between curriculum management and instructional leadership. These findings suggest that, although inter-connected, curriculum management and instructional leadership are separate concepts. Respectively, they are the distinction between management and leadership.

\subsection{Instructional leadership, Social Justice and Critical Pedagogy}

Nelson Mandela, alumnus of one of the schools in this study stated:

Education is the most powerful weapon which you can use to change the world." Education is the key to eliminating gender inequality, to reducing poverty, to creating a sustainable planet, to preventing needless deaths and illness, and to fostering peace [34].

It is evident from Mandela's statement that that education has frequently been regarded as a weapon against poverty and social injustice. In line with this theme Alison lamented:

Education for just one learner, the situation of their lives can change. If our education can move one family out of poverty, then life can be better for them. If this school can achieve this, then I have been a successful principal.

This excerpt gives expression to Alison's vision as an educational leader. She believes that education is an agent of social justice. Alison's statement "If our education can move one family out of poverty, then life can be better for them", mirrors the aim of critical pedagogy. Flecha \& Soler [35] posit that critical pedagogy requires instructional leaders to address issues of inequality, poverty and oppression. Alison articulates her vision for instructional leadership and critical pedagogy through the statement "If this school can achieve this [address poverty through education], then I have been a successful principal."

Alison offers an extended vision of the association between instructional leadership and critical pedagogy. Expressing this as access to tertiary education, she commented:

I think that the most important aspect of this school is the fact that we do what our vision and mission is. It is clear .... We build the bridge for the rural child to go to tertiary. If they can go to tertiary that means, we have done our job. If they can go to tertiary and get employment, the lives of their family will change.

Alison's statement articulates the liberating power of education. She believes that access to tertiary institutions provides access to employment and therefore a departure from poverty. Alison stated "If they can go to tertiary and get employment, the lives of their family will change." 
The literature draws a distinction between critical feminist pedagogy and instructional leadership. The latter relates to the structural and technical aspects of leading for learning. Alison's statement suggests a far closer alignment between the two. In this interpretation, feminist instructional leadership is demonstrated when instructional leadership is harmonised with critical pedagogy and directed towards social justice. Unlike curriculum management, instructional leadership offers educational leaders an opportunity to develop into critical pedagogues. Whereas being an instructional leader does not make one a critical pedagogue, we argue however, that being an instructional leader is a prerequisite for being a critical pedagogue.

\subsection{An Alternative Interpretation of Instructional Leadership}

Responding to the disadvantaged socio-economic conditions of rural communities, two participants enacted instructional leadership that demonstrated a departure from main stream individualistic interpretations.

Firstly, Jane co-founded the South Africa Extraordinary Schools Coalition (SAESC). Her actions reflect a key imperative of instructional leadership, namely, the creation of a learning community [36]. Replacing individualism, this initiative emphasised collaboration while addressing instructional leadership practices and curriculum development. The establishment of the SAESC portrays Jane's response to McLaren's [16] call to educational leaders. He agitates for a critical reflection on one's own pedagogies in relation to how students may be oppressed according to race, class or gender. The schools associated with the SAESC are located in disadvantaged communities where a large majority of the learners are black. Historically and geographically, the demographic profile of the learners suggests that they are socio-economically disadvantaged.

The coalition states that its main focus areas are, "classroom practice and instructional leadership" [37]. The effectiveness of the curriculum delivery in SAESC schools is portrayed through high quality academic results. In 2012, Spring Valley College achieved a matric pass rate of $100 \%$, and 100\% Bachelor passes. Furthermore, in 2013 matric pupils achieved an average pass rate of $97 \%$. This pass rate is $18.8 \%$ above the national average for 2013 [37]. We argue that the founding of the SAESC represents an alternative interpretation of instructional leadership. This assertion is prompted by Mulford \& Silins [38], who contend that the ultimate effectiveness of a principal's instructional leadership efforts is based upon the impact achieved on students learning and development.

A combination of collaborative instructional leadership practices and an acknowledgement of social contexts suggest that Jane has demonstrated feminist instructional leadership. Porter and Daniel [39] point out that feminist leader "are collaborative and pay attention to social contexts". Furthermore, the SAESC represents a shift in power from the education department to principals. Through these actions, SAESC principals have claimed power to enact instructional leadership. Moreover, the power hierarchies imposed by the bureaucracy of education departments, has been reduced. While direct colonial rule may have disappeared in South Africa, colonialism in its multiple guises is enacted through 'power over' leadership relationships. These findings suggest that claiming power is a significant step towards the ultimate decolonisation of education.

We contend that the SAESC is an enactment of critical pedagogy. Jane's approach to instructional leadership is underpinned by a desire to address issues of social justice. Responding to questions which probed her role as a curriculum leader, she commented:

... if the leadership I provide in this school does not lead to real improvement in the lives of the children, we're wasting our time. And by improvement I mean both for them as people but in the quality of their lives ... where they live and their standard of living.

In this excerpt Jane interprets instructional leadership as those practices which directly address issues of social justice. Her statement, "by improvement I mean both for them as people but in the quality of their lives" suggests that her instructional leadership addresses the prevailing socio-economic conditions in disadvantaged rural communities. Instructional leadership with a social justice agenda is transformative. Kincheloe [40] points out that transformative approach to curriculum delivery are directed at "transforming relations of power which are oppressive and which lead to the oppression of people". We contend that Jane has demonstrated the characteristics of a transformative intellectual. Indeed, as a critical pedagogue, she has demonstrated critical feminist leadership underpinned by social justice and transformative leadership imperatives.

Remaining cognisant of the contextual impact on leading in disadvantaged rural communities, Mary presents the second alternative interpretation of instructional leadership. This interpretation is termed the "Pedagogy of Reciprocity". Rejecting the emphasis on individualism featured in mainstream instructional leadership, Mary initiated constructive curriculum engagements with educationalists beyond the confines of her own school. This contribution is manifested through collaborative interactions between learners and teachers from Rolling Hills High School and St Michael's College. St Michael's College, is a pseudonym for an independent boarding school for boys in Grahamstown. It is the reciprocity of this initiative, however, that sets Mary's innovation apart from other initiatives.

Mary explained the relationship between the two schools as follows:

We have a relationship with [St Michael's] College in Grahamstown, we both date back to 1885 . So I am the one who sees to it we have that inter relationship with 
[St Michael's College]. We share ideas and visits. We learn from them, but at the same time it is not only about getting something from them for them coming to [Rolling Hills High School] is a learning experience as well. We have relationship of being there for each other, we work together with their team, they will come and maybe spend five days with us, and then we will go there.... Maths, curriculum development and stuff like that. I am involved in that, but the real interest comes from the teachers. I like to see them, you, know, like leading in their own subjects. Sometimes we will take learners to share classes in Grahamstown. They will come back feeling more motivated, with their spirits being triggered to do more or to see themselves with fresh ideas, we can do this too!

In this excerpt, Mary explains the curriculum benefits of reciprocal relationship with St Michael's College. In these interactions, ideas are shared and mutual benefit is derived from the contact between the schools. Mary's statement, “...we share ideas and visits. We learn from them, but at the same time it is not only about getting something from them for them coming to [Rolling Hills High School] is a learning experience as well" outlines the reciprocity of the interactions between the two schools. The reciprocal curriculum relationship also serves as an opportunity for Mary to provide leadership. Whilst the phrase: "I am involved in that" indicates Mary's leadership role in this process, it is the extract, "... but the real interest comes from the teachers" that is significant. This excerpt suggests a reduction of role power and less hierarchical leadership relationships.

In addition to the curriculum benefit realised, the Pedagogy of Reciprocity unearthed benefits on a deeper level. Mary continued by stating:

I believe that everybody has something of value to give ... I am reminded of a letter sent to me by a boy in grade ten when [St. Michael's College] first came here. He came from a very rich family, they had everything money could but, so he wrote this letter to his father, apparently his father is in England... Telling his father about the importance of valuing people, about humanity ... Now he comes with poor kids, listening to them in the same classroom, listening to their experiences, looking at the way they are dressed. It made him looks at life differently; even change his career path, maybe now to consider helping humanity. It is about the principles and values, about knowing that we are our brothers' keepers. So, for the educators as well, they will come and see us struggling, we do, this ... They see us as role models. People who are very strong, people who are motivating, to look at life differently, really! It makes them want to assist more, to move out of their comfort zone. In the way that they have helped us in many ways, we have given a lot to them, but I think this is at a much deeper level. You can't buy that!

In this excerpt, Mary points out that learner at St Michael's received far more than they gave. Mary's response provides an inspiring account of how the pupils from St Michael's College developed a deeper sense of humanity. They became more aware of the value of others, and were challenged to reflect on their own values and principles. The spirit of reciprocity produced a significant shift in the minds of many learners from St Michael's College. The shift is personified on the phrase "about knowing that we are our brothers' keepers". This statement suggests an alternative interpretation to power. Instead of the St Michael's learners being in a position of power over the Rolling Hills High learners, they were empowered through their engagement on a human level. This finding reflects in Blackmore's [3] description of power in feminist leadership. She posits that feminist leadership views "power as multi-dimensional and multi-directional", and that feminist leadership "looks to empower others rather than have power over others". While Mary is not a professed feminist, her interpretation of power represents a feminist approach to leadership.

\section{Conclusions}

This paper sought to explore the interpretation of instructional leadership by female educational leaders in disadvantaged rural communities. Whilst it is acknowledged that the historic schools are not a homogeneous collection of schools, and that the selection of schools in rural contexts presents certain limitations to the findings of this study, the participants' unearthed alternative interpretations within the context of disadvantaged rural communities. Drawing on critical feminist theory, it found, firstly, that the administrative practices of curriculum management do not necessarily constitute instructional leadership. Furthermore, while a necessary part of school effectiveness, it was found that when curriculum management practices dominated time and attention, an educational leader's ability to enact instructional leadership was compromised. Secondly, within the complexities of instructional leadership and social justice, educational leaders addressed issues of social justice when instructional leadership was harmonised with critical pedagogy. In this way education acts as a powerful weapon against social injustice. It was also argued that while instructional leaders are not necessarily critical pedagogues, being an instructional leader is a prerequisite for being a critical pedagogue. The third finding explored alternative interpretations of instructional leadership. The discussions outlined two collaborative initiatives which demonstrated a departure from mainstream instructional leadership. The first was the SAESC which privileged collaborative engagements as opposed to the emphasis of individualism which is often found in mainstream instructional leadership 
narratives. Furthermore, we argued that replacing hierarchical power structures in favour of 'power through' leadership relationships, created approbatory conditions for the ultimate decolonisation of education. It was also argued that the SAESC is an enactment of critical pedagogy where transformative leadership practices address issues of social injustice. The second initiative, termed the 'Pedagogy of Reciprocity', rejected hierarchical relationships and bureaucratic rationality in instructional leadership practices. The 'Pedagogy of Reciprocity' reduced hierarchical structures in the leader-follower relationship which resulted in power being interpreted as multi-directional and multi-dimensional. Whilst the findings did not dispute the tenets of mainstream instructional leadership, in this interpretation, instructional leadership was fully enacted through reciprocated relationships. The findings of this study give rise to issues related to the decolonisation of education in South Africa. These include, but are not limited to social justice and the dismantling of rigid hierarchical power structures. Having experienced colonialism and Apartheid, the historical schools bear the scars of the ideological residue of these historical eras. This provides an opportunity for further research which, from a critical feminist perspective, could interrogate the factors that prevent the historic schools from shedding their ideological baggage of the past.

\section{Acknowledgements}

We acknowledge, with gratitude, the Executive Director and the staff of the Historical Schools Restoration Project for granting access to the research sites.

Gratitude is expressed to the SANPAD (South African Netherlands Partnership for Alternatives in Development) for their financial contribution to this study.

We remain deeply indebted to the participants of this study who, as leaders of schools in disadvantaged rural communities, willingly shared their lived daily experiences with us.

\section{REFERENCES}

[1] Perumal J, Post-Apartheid South Africa: Creating critically leaderful schools that make a difference, Online available from www.cew.imich.edu

[2] Hallinger P, Wen-Chung W, Assessing instructional leadership with the principal instructional management rating scale, Online available from

https://books.google.co.za/books?id=imynCQAAQBAJ\&dq= conditions + in + the + schoos + that + directly + impact + learning $+o$ utcomes+for+students + hallinger+wen+chung\&sousou $=g b s \_n$ avlinks_s

[3] Blackmore J, Educational leadership: A feminist critique and reconstruction. In J. Smyth (ed.), Critical Perspectives on
Educational Leadership 63-87, Online available from https://books.google.co.za/books?id=CIiNAgAAQBAJ\&pg= PA88\&dq=feminist+leadership + decision + making + lather\&lr= \&source $=$ gbs_toc_r\&cad $=3 \# \mathrm{v}=$ onepage $\& \mathrm{q} \& \mathrm{f}=$ false.

[4] Summer J, Relations of suspicion: Critical theory and interdisciplinary research. History of Intellectual Culture, Online available from

http://www.ucalgary.ca/hic/issues/vol3/7

[5] B. hooks, Talking Back Thinking Feminist, Thinking Black, South End Press, Boston, 1989.

[6] A. E. Cudd, R. O. Andreason, Feminist Theory. A philosophical anthropology. Victoria: Blackwell Publishing, Victoria, 2005.

[7] Lyman I L, Strachan J, and Lazaridou, A Shaping Social Justice Leadership: Insights of women educators worldwide, Online available from

https://books.google.co.za/books?id=TiCE2cFSKew\&dq=soc $\mathrm{ial}+$ justice + feminismauthentic + leadership\&source $=\mathrm{gbs} \_$navli nks_s.

[8] G. Edwards Women leading in Disadvantaged School Communities: A Case Study of the Historical Schools Restoration Project. Unpublished $\mathrm{PhD}$ thesis, University of Johannesburg, South Africa, 2016.

[9] T. Bush, Theories of Educational Leadership and Management 4th Edition, SAGE Publishers Ltd, London, 2011.

[10] J. T. Zikhali, Female Zimbabwean school heads ascurriculum leaders in disadvantaged school contexts. $\mathrm{PhD}$ thesis, University of Johannesburg, South Africa, 2013.

[11] N. Hartsock, Money, Sex and Power, Longman, New York, 1983.

[12] I. M. Young, Justice and the Politics of Difference, Princeton University Press, Princeton, 1990.

[13] Allen A, Feminist perspectives of power, Online available from http://plato.stanford.edu/archives/sum2014//entries/fe minist-power/>.

[14] J. Gore, What we can do for you! What can "we" do for "you"? In C. Luke and J. Gore J (eds.), Feminismsand Critical Pedagogy, pp. 54-72, Routledge, New York, 1992.

[15] M. Aliakbara, E. Faraji, Basic principles of critical pedagogy. Second International Conference on Humanities, Historical and Social Sciences, Singapore, pp. 58-74, 2011.

[16] P. McLaren, Life in Schools. An introduction to critical pedagogy in the foundations of education (3rd ed.), Longman, New York, 1988.

[17] P. Freire, Pedagogy of the Oppressed, Herder \& Herder, New York, 1970.

[18] Giroux H, Teachers as Intellectuals: Toward a critical pedagogy of learning, Online available from https://books.google.co.za/books?id=1Opyme28anEC\&pg=P $\mathrm{R} 3 \& \mathrm{dq}=$ giroux + critical + pedagogy $\& \mid \mathrm{r}=\&$ source $=$ gbs_selecte d_pages \&cad $=3 \# v=$ onepage $\& q=$ Giroux $\% 20$ critical $\% 20$ peda gogy\& $\mathrm{f}=$ false

[19] A. Darder, P. Mayo, and J. Paraskeva, The internationalization of critical pedagogy: An introduction. In A. Darder. P. Mayo P and J. Paraskeva (eds.), International 
Critical Pedagogy Reader, pp.1-14, Routledge, New York, 2016.

[20] Balfour R, Our education needs an extreme makeover. Sunday Times, 12 January, 4, 2014.

[21] P. Lather, Post-critical pedagogies: A feminist reading. In Luke $\mathrm{C}$ and Gore $\mathrm{J}$ (eds.), Feminisms and Critical Pedagogy, 120-137, Routledge, New York, 1992.

[22] Yoon K H, Affecting the transformative intellectual: Questioning "noble" sentiments in critical pedagogy and composition, Online available from $\mathrm{http} / / / j a c o n l i n e j o u r n a l . c o m$

[23] Perumal, J, Critical pedagogies of place: Educator's personal and professional experiences of social (in)justice: Teacher and Teacher Education, Online available from http://www.sciencedirect.com/

[24] A. A, Glatthorn, Supervisory Leadership: Introduction to instructional supervision, Harper Collins Publishers, United States of America, 1990.

[25] T. Thacker, J. S. Bell, and F. P. Schargel, Creating School Cultures that Embrace Learning. What successful leaders do. Eye on Education, Larchmont, 2009.

[26] R. L. Irwin, A Circle of Empowerment: Women, education and leadership, Albany State University of New York Press, New York, 1995.

[27] R. Yin, Case Study Research Design Methods (4th ed.), SAGE Inc, California, 2009.

[28] Naidoo B and Perumal J, Female principals leading at disadvantaged schools on Johannesburg, South Africa. Education, Management Administration \& Leadership, Vol. 42, No. 6, Online available emal.sagepub.com.

[29] N. Ndungane N, Historic Schools Restoration Project, Department of Arts and Culture, South Africa, 2008.

[30] S. N. Hesse-Biber, An invitation to feminist research. In S. N. Hesse-Biber and P. L. Leavy (eds.), Feminist Research Practice, 1-26, SAGE, London, 2007.
[31] M. A. Lazar, Politicizing gender in discourse: Feminist critical discourse analysis as political perspective and praxis. In M. A. Lazar (ed.), Feminist Critical Discourse Analysis. Gender, power and ideology in discourse, 1-28, Pelgrave Macmillan, New York, 2005.

[32] F. W. Parkay, E. J. Anctil and G. Hass, Curriculum Leadership: Reading for developing quality educational programs (10th ed.), Pearson, Boston, 2014.

[33] C. Cornbleth, Curriculum in and out of context. Journal of Curriculum and Supervision, Vol. 3, 85-96, 1988.

[34] T. Leon, Opposite Mandela: Encounters with South Africa's icon, Jonathan Ball Publishers, Johannesburg, 2014.

[35] R. Fletcha, and M. Sole, Turning difficulties into possibilities: Engaging Roma families and students in school through dialogic learning. In A Darder, P. Mayo P and J. Paraskeva (eds.), International Critical Pedagogy Reader,279-291, Routledge, New York, 2016.

[36] E. K. McEwan, 7 Steps to Effective Instructional Leadership, Corwin, California: Corwin Press, 2003.

[37] South African Extraordinary Schools Coalition, Online available from

http://www.bridge.org.za/get-involved/communities-of-practi ce/national-south-african-extraordinary-schools-coalition/

[38] B. Mulford and H. Silins, Revised models and conceptualisation of successful school principals in Tasmania. In G. Mulford and B. Edmunds B (eds.), Successful school principals in Tasmania, 45-76, University of Tasmania, Tasmania, 2009.

[39] N. Porter and J. H. Daniel, Developing transformational leaders: Theory to practice. In J. L. Chin, B. Lott, J. K. Rice and J. Sanchez-Hucles J (eds.), Women and Leadership: Transforming visions and diverse voices, 245-263, Blackwell Publishing Ltd, Oxford, 2007.

[40] J. Kincheloe J, Critical constructivism. Peter Lang, New York, 2005. 